\title{
Regional Concentration of The Gross Production Value of Firewood in Paraíba
}

\author{
Luiz Moreira Coelho Junior ${ }^{1}$ (D), Mariana de Castro Burgos ${ }^{2}$ (D), \\ Edvaldo Pereira Santos Júnior ${ }^{1}$ (D), Pablo Aurélio Lacerda de Almeida Pinto \\ ${ }^{1}$ Centro de Energias Alternativas e Renováveis, Universidade Federal da Paraíba - UFPB, João Pessoa/PB, Brasil \\ ${ }^{2}$ Centro de Ciências Sociais Aplicadas, Universidade Federal da Paraíba - UFPB, João Pessoa/PB, Brasil \\ ${ }^{3}$ Faculdade de Ciências da Administração de Pernambuco, Universidade de Pernambuco - UPE, Recife/PE, Brasil
}

\begin{abstract}
This study analyzed the regional concentration of the gross production value (GPV) of firewood in Paraíba from 1994 to 2014. It measured the concentration by means of the Concentration Ratio $[C R(k)]$ of the Herfindahl-Hirschman Index $(H H I)$, Theil's Entropy $(E)$, the Hall-Tindelman Index $(H T I)$, and the Gini Index $(G)$. From the analyses performed, it was concluded that there was growth in the GPV of firewood in Paraíba from R $\$ 2.59$ million to $\mathrm{R} \$ 10.39$ million (in current terms). The $C R(4)$ and $C R(8)$ of the municipalities indicated low concentration; the $C R(4)$ in the microregions presented a moderately low concentration, and the $C R(8)$ had moderately high concentration. The $H H I$ of the municipalities and microregions has a competitive market, and the $H H I$ of the mesoregions has moderate concentration; $E$ corroborated the evidence of $H H I$; HTI presented low regional concentration; $G$ showed medium to strong inequality for mesoregions, weak to medium in microregions and zero to weak in municipalities.
\end{abstract}

Keywords: forest economy, biomass, regional competitiveness. 


\section{INTRODUCTION}

Firewood is one of the oldest energy sources and has importance in the Brazilian energy matrix, where much of its production is transformed into charcoal for industrial and residential consumption. In Brazil, the production of firewood reached 78.25 million $\mathrm{m}^{3}$ in 2016. Of this total, $68.11 \%$ of the firewood came from planted forests (silviculture) and $31.89 \%$ from native forest (wood extraction/logging). The main firewoodproducing regions for that year were the South $(46.15 \%)$, the Northeast (21.27\%) and the Southeast (16.80\%). There is a discrepancy in proportion within these regions regarding origin; in the South and Southeast approximately $95 \%$ of the firewood supply is from silviculture, while in the Northeast, $92.35 \%$ of the firewood comes from wood extraction/logging. The gross production value (GPV) of firewood from Brazilian wood extraction/logging reached R $\$ 626.42$ million, and the Northeast corresponded to $19.98 \%$ in the Caatinga biome (IBGE, 2017).

Firewood has been the main energy source in the Brazilian Northeast since the initial settlement process. The traditional use of firewood grew along with the regional population until the mid-twentieth century. In the early 1990s, 35\% of the primary consumed energy came from this source. Currently, the demand for firewood is still significant because of its availability, being a social energy resource. About $30 \%$ of the energy matrix in the Brazilian Northeast comes from firewood, $90 \%$ of which is illegally and inadequately obtained. As a consequence, it accelerates the desertification process due to a loss of soil fertility and water scarcity, resulting in biodiversity loss (Campello et al., 1999; Paraíba, 2004, Carvalho, 2012; SFB, 2017).

In 2016, Paraíba state produced $560,192 \mathrm{~m}^{3}$ of firewood, with $86.7 \%$ coming from wood extraction/logging. The state's demand for firewood is for households and the industrial sector. A large part of this wood is destined to kilns for drying and burning ceramic products in the pottery sector. The need to evaluate the market structure of firewood in Paraíba is useful to help in decision-making, either in guiding public policies or in establishing managerial strategies by firms. This evaluation as a form of quantifying the structural component plays a fundamental role within the structure-conduct-performance paradigm, with wide application in studies on Industrial Economy (Zheng \& Kuroda, 2013; Lopez et al., 2014; IBGE, 2017).
An industrial concentration analysis relates the market power exercised by the firms and the competition. Calculating concentration indices provides empirical analytical elements of the industry structure and shows the extent of market competitiveness. With these indicators it is possible to measure the market's performance degree, reflecting the participation of the developed economic activities, analyzing the industry structure and its competitiveness (Possas, 1999; Coelho et al., 2010).

In recent years Hilgemberg \& Bacha (2001), Noce et al. (2008), Coelho et al. (2010, 2013), Heimann et al. (2015), Coelho (2016) and Schettini et al. (2016) performed trials for market concentration in the forest sector

In view of the above, there is no deepening analysis regarding the regional production of firewood in Paraíba aiming to understand the development of economic activity and spatial distribution strategies in the state. Therefore, this study analyzed the regional GPV concentration of firewood in Paraíba from 1994 to 2014 .

\section{MATERIAL AND METHODS}

\subsection{Study object}

The data used to measure the regional GPV concentration of firewood in Paraíba state from 1994 to 2014 are available in the Production of Plant Extraction and Silviculture (PEVS) through the Automatic Recovery System (SIDRA) of the Brazilian Institute of Geography and Statistics (IBGE, 2017). The firewood concentration analysis was performed via geographic clippings of the municipalities, microregions and mesoregions of Paraíba state.

In order to contextualize the GPV firewood scenario, the evolution of the mesoregions for the years 1994, $1998,2002,2006,2010,2014$ was analyzed to evaluate the changes (gains and losses) of firewood GPVs in Paraíba and mesoregions the geometric growth rate (GGR). According to Cuenca \& Dompieri (2017), the GGR is obtained by $G G R[\%]=\left[\Delta t \sqrt{\frac{C_{f}}{C_{0}}}-1\right] * 100$, in which $C_{f}$ is the GPV of Paraíba firewood and its mesoregions referent to 2014; $C_{0}$ is the GPV of Paraíba firewood and its mesoregions referent to 1994; $\Delta \mathrm{t}$ is the temporal variation of consumption (expressed in years). 


\subsection{Concentration indicators}

The indexes used to measure the regional concentration were: Concentration Ratio [CR( $k)]$, Herfindahl-Hirschman Index $(H H I)$, Theil Entropy $(E)$, Hall-Tindelman Index $(H T I)$, and Gini Index $(G)$. Each one of these indicators has particular characteristics that help to evaluate and indicate the degree of concentration in order to provide a more robust analysis of the regional GPV market of firewood in Paraíba. The following sections present a characterization of each one.

\subsection{Concentration ratio}

The concentration ratio $[C R(k)]$ analyzes the market share of $k$ (being $k=1,2, \ldots, n$ ), as proposed by Bain (1959). This indicator for the study object was used to analyze the regions of greater GPV of firewood for Paraíba, given by the equation $C R(k)=\sum_{i=l}^{k} S_{i}$, in which $S_{i}=$ market share (in percentage) of the region $i$ for firewood production.

Table 1 shows the different concentration levels and respective classifications for $C R(4)$ and $C R(8)$, normally used in industrial studies as a way of measuring the degree of concentration through index elevation. In this study, it was considered $C R(4)$ and $C R(8)$ of municipalities and microregions, and the participation of the 20 largest [CR(20)] and the 30 largest [CR(30)] firewood-producing municipalities in Paraíba. The $C R(k)$ was not analyzed for the geographic clipping of the Paraíba mesoregions because there were only 4 regions, which prevented classification and analysis by means of Table 1 .

\subsection{Herfindahl-Hirschman Index}

Proposed by Hirschman (1945), the HerfindahlHirschman Index $(H H I)$ is a market concentration analysis tool. The HHI evidences the square participation of each region in the GPV of firewood in Paraíba.
$H H I$ aggregates industrial concentration indicators using the data from all regions (summary indices) as follows: $H H I=\sum_{i=1}^{n} S_{i}^{2}$, in which $S_{i}=$ the participation of the region $i$ (municipalities, microregion and mesoregion) in the GPV of firewood of Paraíba; $n=$ quantity of participating GPV firewood regions in Paraíba at regional levels.

The index value is found between $1 / n$ (lower limit) with equal shares of each region and 1 (maximum concentration), a monopoly condition. In inter-temporal comparative analyses, Resende (1994) suggested an Adjusted Herfindahl-Hirschman Index (HHI') as $H H I^{\prime}=\frac{1}{n-1}(n H H I-1) ; n>1$.

The $H H I$ ' assigns an interval between 0 and 1 , where as the index moves away from zero, the concentration increases. If $H H I^{\prime}<0.1$ shows a highly competitive market, the interval $0.10 \leq H H I^{\prime}<0.15$ recommends a non-concentrated market. An index between $0.15 \leq H H I^{\prime} \leq 0.25$ indicates moderate concentration, and $H H I^{\prime}>0.25$ gives a high concentration.

\subsection{Theil's Entropy Index (E)}

Proposed by Theil (1967), the Entropy Index was initially established to examine the informational content of the message that firms would provide in the face of a certain event. The index also applies to an evaluation of the regional firewood concentration in Paraíba. The equation used was: $E=-\sum_{i=1}^{n} \ln \left(S_{i}\right)$, in which $S_{i}=$ the participation of the region $i$ (municipalities, microregion and mesoregion) in the GPV of firewood of Paraíba; $n$ = quantity of participating GPV firewood regions in Paraíba at regional levels; $l n=$ neperian logarithm.

The Entropy Index measures the inverse of the $\mathrm{HHI}$ concentration, where the index ranges from 0 (maximum concentration) to 1 (minimum concentration). The lower

Table 1. Concentration Ratio Classification $[C R(k)]$.

\begin{tabular}{ccc} 
Degree of Concentration & CR(4) & CR(8) \\
Very high & $C R(4) \geq 75 \%$ & $C R(8) \geq 90 \%$ or more \\
High & $65 \% \geq C R(4)>75 \%$ & $85 \% \geq C R(4)>90 \%$ \\
Moderately High & $50 \% \geq C R(4)>65 \%$ & $70 \% \geq C R(8)>85 \%$ \\
Moderately Low & $35 \% \geq C R(4)>50 \%$ & $45 \% \geq C R(8)>70 \%$ \\
Low & $C R(4)<35 \%$ & $C R(8)<45 \%$ \\
\hline
\end{tabular}

Source: Bain (1959). 
the index value, the more regionally concentrated the GPV of firewood in Paraíba. In monopoly situations, the Entropy value is equal to zero. The upper limit is equal to $\ln (n)$, meaning that the regions have equal market shares and minimum concentration (Resende \& Boff, 2002).

In a similar way to that suggested for $H H I$, Resende (1994) suggested the Entropy to be adjusted for inter-temporal analyses as follows: $E^{\prime}=-\frac{1}{\ln (n)} \sum_{i=1}^{n} s_{i} \ln \left(s_{i}\right)$. Thus, the entropy changes to 0 for monopoly (maximum concentration), and 1 for perfect competition (minimum concentration).

\subsection{Hall-Tindelman Index}

For Bikker \& Haaf (2001), the Hall-Tindelman index $(H T I)$ infers that the share of each region receives an equal weight to its ranking in the construction of the index, and thus the highlight becomes the total of regions with GPV of firewood in Paraíba. The equation is $H T I=\frac{1}{2 \sum_{i=1}^{n}\left(i . s_{i}\right)-1}$, in which $S_{i}=$ market share in percentage of the region $i$ (municipalities, microregion and mesoregion) for the production of firewood; $n=$ number of participating regions in the production of firewood; $i=$ the position in the GPV ranking of firewood in at the regional level as a whole. The value of the HTI is between $1 / \mathrm{n}$ and 1 , it approaches the first condition at perfect competition and reaches one (1) in the case of monopoly (high concentration).

\subsection{Gini Index}

Developed by Gini (1912), the Gini $(G)$ coefficient is an index which originally measured income inequality, but it can also be used to measure the degree of GPV inequality of Paraíba firewood, with the equation $G=1-\left[\frac{\sum_{i=1}^{n}\left(s_{i j}+s_{i}\right)}{n}\right]$ in which $n=$ number of regions with
GPV of firewood in Paraíba; $S_{i j}=$ cumulative participation of regions in increasing order; $S_{i}=$ market share in percentage of the regions with GPV of firewood, $i$ of the total consumed in the industry.

The index is between 0 and 1 and can be classified between the intervals: $0.101-0.250=$ zero to weak inequality; $0.251-0.500=$ weak to medium inequality; $0.501-0.700=$ medium to strong inequality; 0.701-0.900 = strong to very strong inequality; $0.900-1.000=$ very strong to absolute inequality.

\section{RESULTS AND DISCUSSION}

Table 2 shows the evolution of firewood production value in current values, originating from native forest in the mesoregions of Paraíba from 1994 to 2014. There was an increase in the value of firewood production from R\$2.59 million in 1994 to R\$ 10.39 million in 2014 , constituting an increase of $301.2 \%$. This increase was due to these regions presenting a great demand for energy from forest biomass for supplying industrial poles, mainly of lime and red ceramics.

From 1994 to 2014, Sertão Paraibano obtained the largest firewood rate in the period, with an average participation of $51.77 \%$. In 2010 alone, Sertão lost the first place to Borborema. Agreste Paraibano occupied the third place throughout the analyzed period. Mata Paraibana mesoregion had a very small contribution in the state context due to most of the forest fragments being designated as permanent preservation areas, legal reserves and conservation units.

From 1994 to 2014, the average annual growth of the GPV of firewood in Paraíba was 7.19\% per year. From the mesoregions, Borborema grew by $9.95 \%$ per year, followed by Sertão Paraibano (7.17\% per year), Agreste Paraibano (3.46\% pa) and Mata Paraibana (1.70\% pa).

Table 2. Evolution of the gross production value (current terms) of firewood in the Paraíba mesoregions, in thousands of Reais, from 1994 to 2014.

\begin{tabular}{lccccccc}
\multicolumn{1}{c}{ Mesoregions } & $\mathbf{1 9 9 4}$ & $\mathbf{1 9 9 8}$ & $\mathbf{2 0 0 2}$ & $\mathbf{2 0 0 6}$ & $\mathbf{2 0 1 0}$ & $\mathbf{2 0 1 4}$ \\
\hline Sertão Paraibano & 1,402 & 1,739 & 1,832 & 2,132 & 2,324 & 5,596 \\
\hline Borborema & 525 & 867 & 958 & 1,030 & 2,461 & 3,499 \\
Agreste Paraibano & 630 & 444 & 673 & 787 & 964 & 1,244 \\
Mata Paraibana & 35 & 71 & 3 & 5 & 37 & 49 & 10,388 \\
\hline Paraíba & 2,592 & 3,121 & 3,466 & 3,954 & 5,786 & \\
\hline
\end{tabular}

Source: IBGE (2017). 
In view of the high average growth rates and the GPV firewood concentration in Sergão Paraibano and Borborema mesoregions, it was necessary to understand the behavior at the municipal and micro-regional levels. Figure 1 shows the GPV concentration ratio $[C R(k)]$ of Paraíba firewood through its microregions and municipalities from 1994 to 2014.

The concentration ratio of the four largest microregions $\left[C R(4)_{\text {Micro }}\right]$ (Figure 1a) presented an average of $45 \%$ in the studied period, which characterized a moderately low concentration according to the classification of Bain (1959). The year with the greatest concentration was in 1994 with $C R(4)_{\text {Micro }}$ equal to $55.79 \%$, and the lowest was $39.13 \%$ in 1996 . During the studied period, the $C R(4)_{\text {Micro }}$ showed moderately high concentration tendencies, reaching $50.97 \%$ in 2014 . The micro regions of Itaporanga and Cariri Ocidental participated the most in the $C R(4)_{\text {Micro }}$ throughout the studied period, maintaining its productions in the first place in the state ranking. Other microregions that also participated in some periods for the $C R(4)_{\text {Micro }}$ were: Serra do Teixeira, Curimataú Ocidental, Seridó, Catolé do Rocha, and Souza.

The concentration ratio of the eight largest microregions $\left[C R(8)_{\text {Micro }}\right.$ ] for GPV of firewood in Paraíba presented an average of $72 \%$, which characterizes a moderately high concentration. $C R(8)_{\text {Micro }}$ had higher concentration (81.57\%) in 1995 due to greater participation of the eight largest microregions [Sousa (20.09\%), Curimataú Ocidental (12.95\%), Catolé do Rocha (12.03\%), Seridó Ocidental Paraibano (8.99\%), Seridó Oriental Paraibano (8.26\%), Cariri Oriental $(8.06 \%)$, Serra do Teixeira (6.01\%) and Cajazeiras
(5.19\%)] for the GPV of firewood in Paraíba. The lowest concentration (63.76\%) occurred in 1996, decreasing the participation of the eight largest microregions [Serra do Teixeira (11.67\%), Itaporanga (9.58\%), Catolé do Rocha (9.37\%), Cariri Ocidental (8.50\%), Cajazeiras (6.90\%), Seridó Oriental Paraibano (6.75\%), Sousa (5.79\%) and Patos (5.18\%)] for the GPV of firewood of Paraíba, generating R\$2.47 million.

The microregions that participated in the $C R(8)$ Micro throughout the study period were: Souza, Serra do Teixeira and Catolé do Rocha. Other microregions that also participated at least one time in forming the $C R(8)_{\text {Micro }}$ were: Itaporanga, Curimataú Ocidental, Curimataú Oriental, Cariri Ocidental, Cariri Oriental, Seridó Ocidental, Seridó Oriental, Patos, Cajazeiras, Piancó, and Brejo Paraibano.

As the analysis scale of the GPV concentration of wood from microregions is changed to the municipal level. A decrease in the concentration is observed (Figure 1b), which presents the concentration ratio of the four largest municipalities $\left[C R(4)_{\text {Munic }}\right]$ for GPV of firewood in Paraíba. $C R(4)_{\text {Munic }}$ presented a mean in the study period of $15.05 \%$, indicating a low concentration, according to Table 1 . The municipalities that participated in the composition of the $C R(4)_{\text {Munic }}$ in this study were: Conceição, Taperoá, Itaporanga, Boqueirão, Souza, Barra de Santa Rosa and Pombal.

For the eight municipalities $\left[C R(8)_{\text {Munic }}\right.$, the GPV concentration ratio of firewood in Paraíba presented an average of $23.77 \%$, which characterizes a concentration considered to be low. The year of greatest concentration (32.20\%) was 1994, due to the greater participation of the eight largest municipalities [Pombal (7.48\%), Sousa
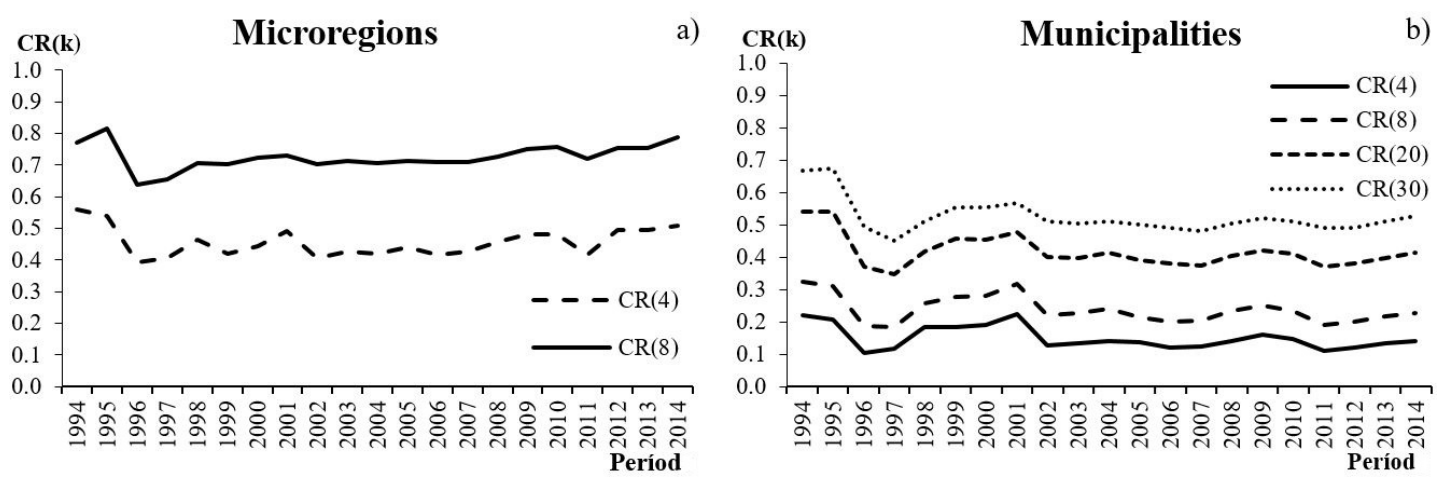

Figure 1. Evolution of the gross production value concentration ratio $[C R(k)]$ of firewood in Paraíba at the microregional $\left[C R(k)_{\text {Micro }}\right]$ (a) and municipal $\left[C R(k)_{\text {Munic }}\right]$ (b) levels, from 1994 to 2014. 
(6.94\%), Princesa Isabel (3.90\%) Solânea (3.78\%), Tavares (2.70\%), Arara (2.58\%), Catolé do Rocha (2.51\%), Belém do Brejo do Cruz (2.31\%)]; whereas 1997 obtained the lowest concentration (18.33\%), due to decreased participation by the eight largest municipalities [Sousa (4.49\%), Conceição (2.79\%), Massaranduba (2.52\%), Manaíra (1.77\%), Umbuzeiro (1.74\%), Itaporanga (1.70\%), Princesa Isabel (1.70\%) and Alagoa Grande (1.61\%)]. The municipalities that participated most at least once in the composition of $C R(8)_{\text {Munic }}$ were: Conceição, Itaporanga, Taperoá, Souza, Boqueirão, Barra de Santa Rosa, Algodão de Jandaíra, Princesa Isabel, Junco do Seridó and Juazeirinho.

The concentration ratio of the 20 largest municipalities $\left[C R(20)_{\text {Munic }}\right]$ with a mean of $41.66 \%$, in an interval of $34.72 \%$ to $54.15 \%$, and of the 30 largest municipalities $\left[C R(30)_{\text {Munic }}\right]$ with a mean of $52.44 \%$, varying between $44.98 \%$ and $67.30 \%$. These data show that the firewood market among the municipalities of Paraíba is not concentrated.
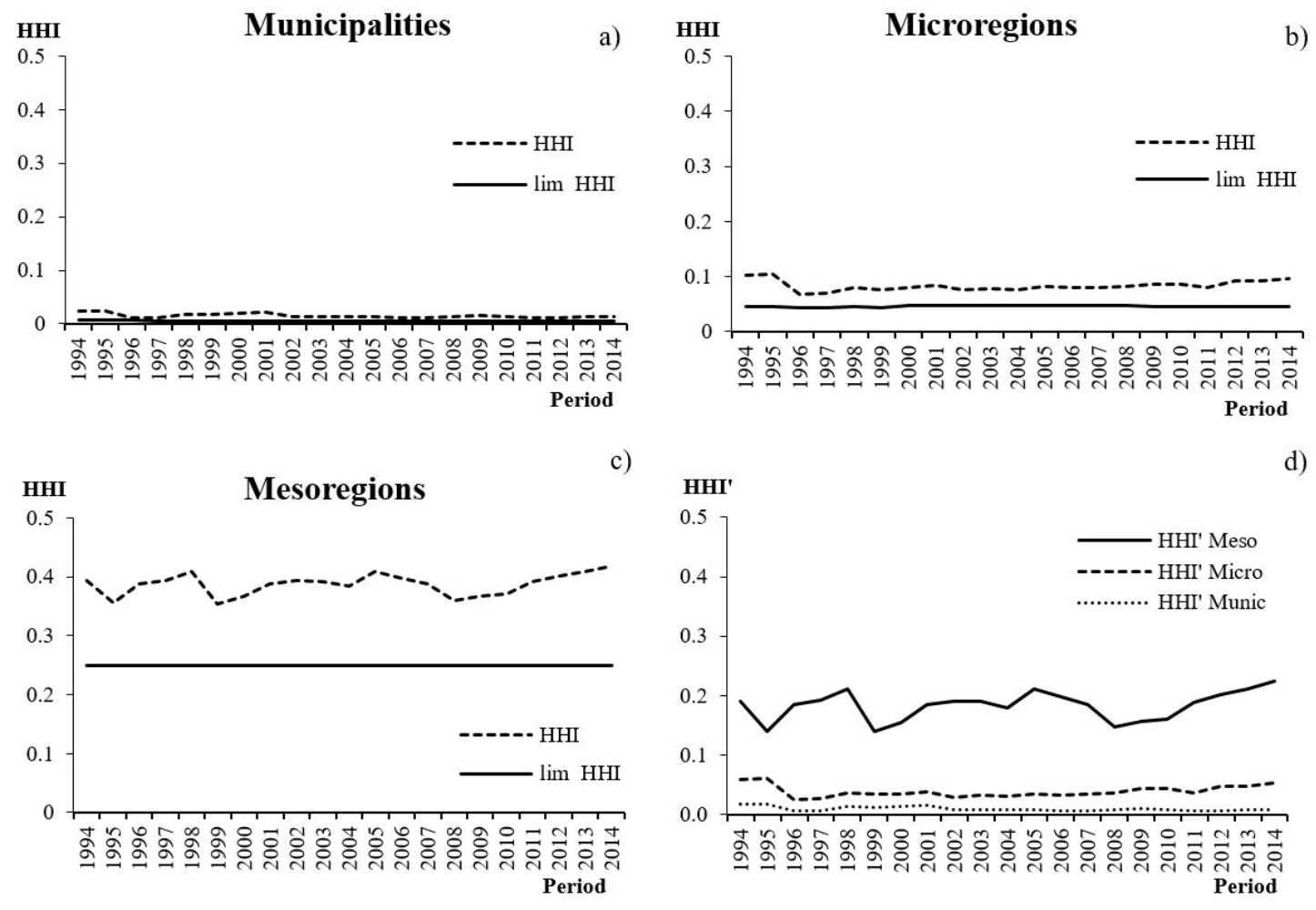

Figure 2 shows the evolution of the HerfindahlHirschman Indices (HHI) of the GPV for firewood in Paraíba through its municipalities, microregions and mesoregions in the period 1994 to 2014 . The indices at the municipal $\left(\mathrm{HHI}_{\text {Munic }}\right)$ and micro-regional $\left(\mathrm{HHI}_{\text {Micro }}\right)$ levels presented a low concentration market, and the index of the mesoregions $\left(\mathrm{HHI}_{\text {Meso }}\right)$ was more concentrated; therefore, less competition between the regions. In general, the $C R(k)$ is a partial index when associated with the $H H I$, which is a summary index presenting pertinent results regarding the regional GPV concentration of firewood at the regional levels in Paraíba.

For the municipalities (Figure 2a), $\mathrm{HHI}_{\text {Munic }}$ obtained an average of 0.01 in the analyzed period, while the LI was 0.005 . The greatest difference $(0.016)$ between $H H I$ and $L I$ was observed in 1994 . The index remained very close to the lower limit throughout the analyzed period, showing low GPV concentration of firewood in Paraiba. In the first year of analysis in 1994, 142 municipalities participated, and in the end in 2014, the number had increased to 189 . The $H H I$ was closer to the $L I$ at the

d)

Figure 2. Herbindahl-Hirschman indexes $(H H I)$ of the gross production value of firewood in Paraíba from 1994 to 2014. (a) Municipalities $\left(H H I_{\text {Munic }}\right)$, (b) Microregions $\left(H H I_{\text {Micro }}\right)$, (c) Mesoregions $\left(H H I_{\text {Meso }}\right)$, and (d) HHI' are the three geographic clippings. 
end of the time series under study, demonstrating greater market competition.

The $\mathrm{HHI}_{\text {Micro }}$ (Figure $2 \mathrm{~b}$ ) in the studied period presented an average of 0.083 , while $L I$ was 0.046 . Observing the difference between $H H I$ and $L I$, the greatest concentration year was 1995 , with a difference of $0.057 \%$. The difference between $H H I$ and $L I$ in 1997 was 0.006 , which characterized the lowest concentration. Participation varied between 21 and 22 microregions in the period under analysis, and the index showed market competition, remaining close to the lower limit over the years, and being very similar to the $H_{H} I_{\text {Munic }}$.

The $\mathrm{HHI}_{\text {Meso }}$ presented a greater distance between its lower limits, which characterized a moderately concentrated market (Figure 2c). The mean $\mathrm{HHI}_{\text {Meso }}$ level in the studied period was 0.387 , while the LI was 0.25 , and the year with the highest concentration was 2014 with a difference of $0.168 \%$ between $H H I$ and LI. Although the number of participating regions was the same, the $H H I_{\text {Meso }}$ indicator varied the most over the years.
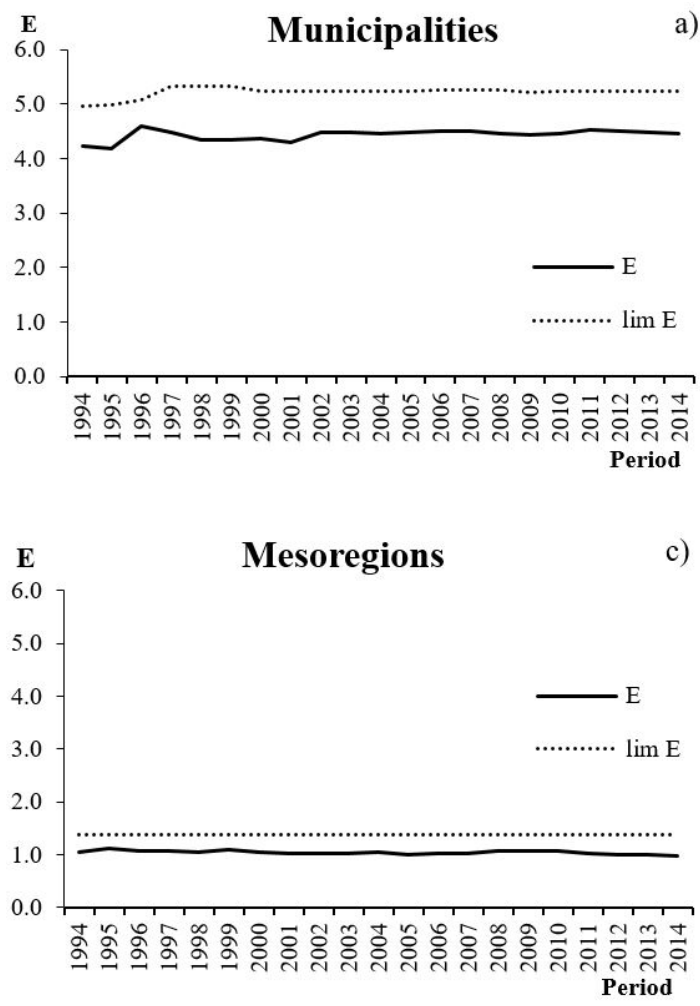

According to the adjusted $H H I\left(H H I^{\prime}\right)$ classification (Figure 2d), the firewood production concentration in the Paraiba mesoregion was the most highlighted, classified with a moderate concentration, while showing a reduced index value over the years. The HHI's of the microregions and municipalities remained very close throughout the analyzed period, presenting a highly competitive firewood production market.

Figure 3 shows the Evolution of the Entropy Index (E) for the GPV of Paraiba firewood from 1994 to 2014. The entropy indicators at the regional levels (municipalities, microregions and mesoregions) of Paraíba showed little variation and remained near the lower limit; however, the entropy of each had a different scale during the analyzed period, corroborating the $H H I$ analysis.

From 1994 to 2014, the municipalities of Paraíba showed the lowest market concentration and the greater distance between the $E_{\text {munic }}$ index and its limit (Figure 3a), with an average of 4.43. The Microregion presented a market with little change in the entropy

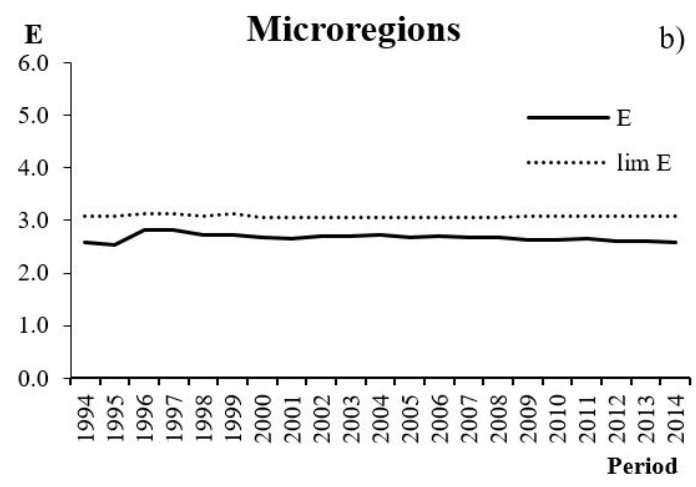

Figure 3. Evolution of the Entropy Index $(E)$ of the gross production value of firewood in Paraíba at regional levels from 1994 to 2014. (a) Municipalities $\left(E_{\text {munic }}\right)$, (b) Microregions $\left(E_{\text {Micro }}\right)$, (c) Mesoregions $\left(E_{\text {Micro }}\right)$, and (d) $E^{\prime}$ as the three geographic clippings. 


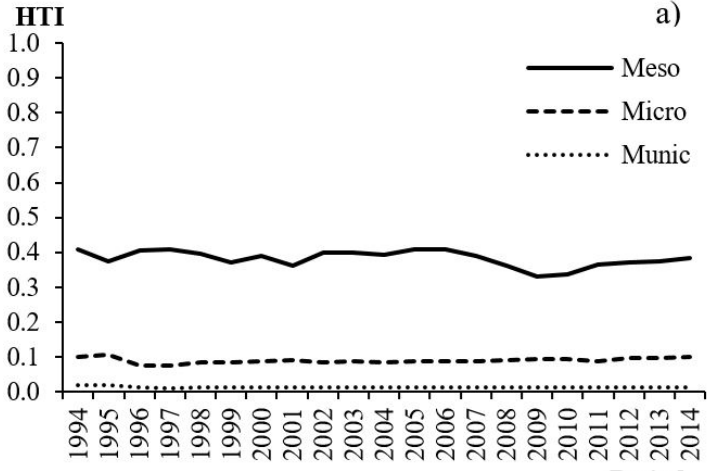

Period

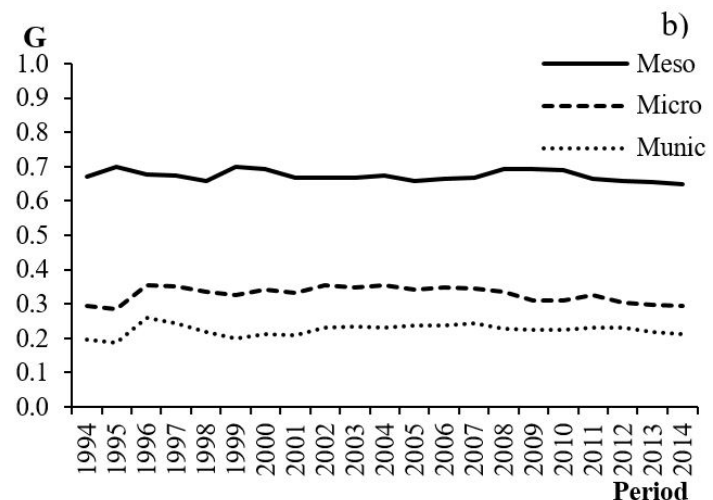

Period

Figure 4. Evolution of the Hall-Tideman (HTI) (a) and Gini $(G)$ (b) indices for the Gross Production Value of firewood in Paraíba at regional levels from 1994 to 2014.

index $\left(E_{\text {Micro }}\right)$, ranking second in the region, with an average of 2.67 and a moderate concentration. The Mesoregion obtained an average of 1.04, being considered the most concentrated region of Paraiba. The entropy index $\left(E_{\text {mess }}\right)$ and its limit remained stable, showing little competition among the mesoregions, in a near monopoly situation. According to the adjusted Entropy Index (E') (Figure 3d), the Paraíba regions showed a structure close to perfect market competition, because their entropy values are close to 1 , which results in minimum market concentration over the years.

Figure 4 shows the evolution of the Hall-Tideman and Gini Indices for the production value of firewood in Paraiba at regional levels from 1994 to 2014. The HTI and $G$ indices showed small variations in relation to the average over the analyzed period, as shown in graphs a and b. According to the HTI (Figure 4a), the Paraiba regions showed a low concentration due to their collaboration of incorporating the ranking into the indicator. The municipality and microregion indicators remained very close to the minimum concentration and with little variation during the analyzed period, presenting high competition.

For the municipalities, $H T I_{\text {Munic }}$ obtained an average of 0.012 with the lowest concentration of firewood production at the regional level, and the $H T I_{\text {Micro }}$ obtained an average of 0.089 . The $H T I_{\text {Meso }}$ varied the most when compared to the other concentration indicators at the regional level. Although the number of participating mesoregions is the same, there has been a trend of decline and growth in firewood production over the years, with an average of 0.382 indicating the highest concentration at the regional level.
Figure $4 \mathrm{~b}$ shows the GPV inequality of Paraíba firewood, which obtained small variations in the index related to the average between the regional levels, without strong declining trends. $G_{\text {Meso }}$ was classified as having medium to strong inequality, presenting an average of $0.673 \%$ due to the concentrated production in the Sertão region of Paraíba and Borborema. The $G_{\text {Micro }}$ indicator averaged $0.328 \%$, which ranks it as weak to average inequality. $G_{\text {Munic }}$ presented an average of $0.224 \%$, classifying it as having zero to weak inequality.

\section{CONCLUSIONS}

From the analyses carried out in this study, it is concluded that:

The GPV evolution of firewood in Paraíba increased from 1994 to 2014 , from $\mathrm{R} \$ 2,592,000.00$ to $\mathrm{R} \$ 10,388,000$ (in current values), respectively. Mean $C R(4)_{\text {Munic }}$ and $C R(8)_{\text {munic }}$ indicated low concentration. The $C R(4)_{\text {Micro }}$ mean was classified as moderately low and $C R(8)_{\text {Micro }}$ was moderately high. The $H H I$ of the municipalities and $\mathrm{HHI}$ of the microregions showed a competitive market structure, and the $\mathrm{HHI}$ of the mesoregions indicated a moderate concentration. The $E$ of the municipalities, the microregions, and the mesoregions corroborate the $\mathrm{HHI}$ evidence in the regional levels under study. The HTI presented low concentration in its regional levels in the municipalities, microregions and mesoregions, respectively, indicating high competition. $G$ showed that inequality at regional levels was classified as medium to strong for mesoregions, from weak to medium in microregions, and zero to weak in municipalities. 
The indicators showed that with the change in the regional clippings, the GPV concentration of firewood in Paraiba was reduced, meaning that it has a higher degree of concentration in the mesoregions than in the microregions, which in turn is more concentrated than the municipalities.

\section{ACKNOWLEDGEMENTS}

The authors wish to thank the Conselho Nacional de Desenvolvimento Científico e Tecnológico (CNPq) for the scholarships awarded by the Institutional Scientific Initiation Scholarship Program (PIBIC), and for the financial support of project no. 454830/2014-9. Thanks are extended to the Coordenação de Aperfeiçoamento de Pessoal de Nível Superior (CAPES) for the post-doctoral fellowship.

\section{SUBMISSION STATUS}

Received: 23 aug., 2017

Accepted: 30 june, 2018

\section{CORRESPONDENCE TO}

\section{Luiz Moreira Coelho Junior}

Centro de Energias Alternativas e Renováveis, Universidade Federal da Paraíba - UFPB, Campus I - Lot. Cidade Universitária, CP 5115, CEP 58051-900, João Pessoa, PA, Brasil e-mail: luiz@cear.ufpb.br

\section{FINANCIAL SUPPORT}

Conselho Nacional de Desenvolvimento Científico e Tecnológico (Grant/Award Number: 'Projeto Universal, no $454830 / 2014^{\prime}$ )

\section{REFERENCES}

Bain J. Industrial organization. New York: Wiley; 1959.

Bikker JA, Haaf K. Competition and concentration review of the literature. Amsterdam: De Netherlands Bank; 2001.

Campello FB, Gariglio MA, Silva JA, Leal AMA. Diagnóstico Florestal da Região Nordeste. Brasília: IBAMA; 1999. (Boletim Técnico, no. 2). Projeto Desenvolvimento Florestal para o Nordeste do Brasil (Projeto IBAMA/ PNUD/BRA/93/033).
Carvalho PP. A convivência com o semiárido como estratégia para o combate à desertificação: uma experiência no Sertão do Araripe. Revista Agriculturas: Experiências em Agroecologia [online], 2012; 9(3). [cited 2017 Apr 14]. Available from: http://aspta.org.br/wp-content/ uploads/2013/04/Agriculturas-2013_SITE.pdf

Coelho LM Jr, Rezende JLP, Avila ES, Oliveira AD, Borges LAC. Analysis of the brazilian cellulose industry concentration (1998 a 2007). Cerne 2010; 16(2): 209-216.

Coelho LM Jr, Rezende JLP, Oliveira AD. Concentração das exportações mundiais de produtos florestais. Ciência Florestal 2013; 23(4), 693-703.

Coelho LM Jr. Concentração regional do valor bruto de produção do pinhão no Paraná. Ciência Florestal 2016; 26(4): 853-861.

Cuenca MAG, Dompieri MHG. Dinâmica espacial da canavicultura e análise dos efeitos sobre o valor bruto da produção, na região dos tabuleiros costeiros da Paraíba, Pernambuco e Alagoas. Revista Economica do Nordeste 2017; 47(4): 91-106.

Gini C. Variabilità e Mutuabilità. Contributo allo Studio delle Distribuzioni e delle Relazioni Statistiche. Bologna: C. Cuppini; 1912.

Heimann JP, Gonçalves K, Dresch AR, Silva JCGL. Concentração de mercado de molduras (frame) importadas pelos Estados Unidos, período de 2005 a 2009. Cerne 2015; 21(1): 59-65. http://dx.doi.org/10.1590/0104776 0201521011435 .

Hilgemberg EM, Bacha CJC. A evolução da indústria brasileira de celulose e sua atuação no mercado mundial. Revista Análise Econômica 2001; 19(36): 145-164.

Hirschman AO. National power and the structure offoreign trade. Berkley: University of California Press; 1945.

Instituto Brasileiro de Geografia e Estatística - IBGE. Sistema IBGE de Recuperação Automática - SIDRA. Produção da Extração Vegetal e da Silvicultura - PEVS [online]. Rio de Janeiro: IBGE; 2017 [cited 2017 Nov 24]. Available from: http://www.sidra.ibge.gov.br

Lopez R, Lopez E, Lirón-España C. Who benefits from industrial concentration? Evidence from U.S. manufacturing. Journal of Industry, Competition and Trade 2014; 14(3): 303-317. http://dx.doi.org/10.1007/s10842-013-0161-1.

Noce R, Silva ML, Souza AL, Silva OM, Mendes LM, Carvalho RMMA et al. Competitividade do Brasil no mercado internacional de aglomerado. Revista Árvore 2008; 32(2): 245-250.

Paraíba. Superintendência de Administração do Meio Ambiente - SUDEMA. Atualização do Diagnóstico Florestal do Estado da Paraíba. João Pessoa: SUDEMA; 2004. 268 p.

Possas MS. Concorrência e competitividade: notas sobre estratégia e dinâmica seletiva na economia capitalista. São Paulo: Hucitec; 1999. 
Resende M, Boff H. Concentração Industrial. In: Hasenclever L, Kupfer D, organizadores. Economia industrial: fundamentos teóricos e práticas no Brasil. Rio de Janeiro: Campus; 2002. p. 73-90.

Resende M. Medidas de concentração industrial: uma resenha. Análise Econômica 1994; 11, 24-33.

Schettini BLS, Silva ML, Jacovine LAG, Alves EBBM, Villanova PH. Avaliação da concentração do mercado mundial de pellets de madeira e as oportunidades para o Brasil. Enciclopédia Biosfera 2016; 13(23): 103-113. http:// dx.doi.org/10.18677/Enciclopedia_Biosfera_2016_009.
Serviço Florestal Brasileiro - SFB. Sistema Nacional de Informações Florestais [online]. Brasília: SFB; 2017 [cited 2017 June 11]. Available from: http://www.florestal.gov. br/snif/producao-florestal/consumo

Theil H. Economics and information theory. Amsterdam: North-Holland; 1967. 488 p.

Zheng D, Kuroda T. The impact of economic policy on industrial specialization and regional concentration of China's high-tech industries. The Annals of Regional Science 2013; 5(3): 771-790. http://dx.doi.org/10.1007/ s00168-012-0522-4. 